\title{
Moral Guidance Models of Students in SMK Ma'arif 1 Kebumen
}

\author{
Mugiarto \\ Universitas Ma'arif Nahdlatul Ulama Kebumen \\ mugiarto520@yahoo.co.id
}

\section{Article History}

accepted 24/09/2019

\begin{abstract}
Adolescence is the golden period for the students. Therefore, the school as an institution of public education to foster in terms of cognitive, psychomotor and affective must be able to see the symptoms change in adolescence all want to know and want to try. The purpose of this study is to describe and learn about moral guidance models in SMK ma'arif 1 Kebumen. The method used in this research is observation, interview and documentation. Form of business that is done school in Moral guidance in SMK ma'arif 1 Kebumen is with a wide variety of activities such as the application of An-Nahdiyah, that is all the action that is rooted in the permission of ahlu sunnah wal jama'ah and extracurricular activities. So it can be concluded, moral guidance, moral and ethics students should continue to be made in istikomah to be the media in shaping the character and morals of students in SMK ma'arif 1 Kebumen.
\end{abstract}

Keywords: Model, Moral Guidance, Students

\begin{abstract}
Abstrak
Masa remaja merupakan masa keemasan bagi para siswa. Oleh karena itu sekolah selaku lembaga pendidikan masyarakat yang membina dari segi kognitif, psikomotorik dan afektif harus mampu melihat gejala perubahan pada masa remaja yang serba ingin tau dan ingin mencoba. Tujuan penelitian ini adalah untuk mendeskripsikan dan mengetahui tentang model pembinaan akhlak di SMK Ma'arif 1 Kebumen. Metode yang digunakan dalam penelitian ini adalah observasi, wawancara dan dokumentasi. Bentuk usaha yang dilakukan sekolah dalam pembinaan Akhlak di SMK Ma'arif 1 Kebumen adalah dengan berbagai macam kegiatan seperti amaliyah An-Nahdiyah, yaitu semua amalan yang bersumber pada amaliah ahlu sunah wal jama'ah dan kegiatan ekstrakurikuler. Sehingga dapat disimpulkan pembinaan akhlak, moral dan etika siswa harus terus dilakukan secara istikomah agar menjadi media dalam membentuk karakter dan akhlak siswa di SMK Ma'arif 1 Kebumen.
\end{abstract}

Kata kunci: Model, Pembinaan, Akhlak, Siswa

Social, Humanities, and Education Studies (SHEs): Conference Series https://jurnal.uns.ac.id/shes

p-ISSN 2620-9284

e-ISSN 2620-9292 


\section{PENDAHULUAN}

Sekolah merupakan tempat yang strategis dalam pendidikan Akhlak. ${ }^{1}$ Sekolah harus memiliki tujuan dan metode dalam menerapkan pendidikan akhlak. Memiliki cara kerja yang bersistem untuk memermudah pelaksanaan kegiatan agar tujuandari pendidikan tercapai. ${ }^{2}$ Oleh karena itu dapat dipahami sekolah merupakan salah satu lembaga pendidikan yang bertujuan untuk membentuk anak didik yang berakhlak mulia dan berbudi pekerti luhur dalam rangka mencerdaskan bangsa. Kemajuan zaman telah merubah gaya hidup sendi kehidupan, terutama di kalangan pelajar. Kebanyakan siswa sangat aktif dalam memanfaatkan kemajuan teknologi. Kehidupan siswa saat ini sering dihadapkan pada permasalahan yang begitu kompleks. Salah satu masalah yang dihadapi saat ini adalah semakin menurunnya tatakrama dan etika moral remaja dalam praktik kehidupan, baik di dalam sekolah, rumah, maupun lingkungan masyarakat. Akhlak merupakan salah satu pondasi dalam keidupan karena mempunyai pengaruh besar terhadap manuasia dan peradaban suatu bangsa. Prilaku moral suatu bangsa akan tercermin dari prilaku moral atau akhlak individu warga masyarakat bangsa tersebut, apabila akhlak individunya baik maka bangsa tersebut menjadi bangsa yang punya peradaban yang baik. Suatu bangsa harus terus berusaha bagaimana individu warga masyarakatnya menjadi baik terutama kalangan remajanya. Di era sekarang perkembangan akhlak siswa banyak mengalami penurunan tidak dipungkiri banyak kasus-kasus yang terjadi di kalangan siswa, seperti tawuran antar pelajar, minuman keras, aborsi, narkoba telah menyentuh dikalangan siswa kita. Hal inilah yang perlu di antisapasi dan jalan keluar karena para siswa merupakan tunas bangsa sebagai penerus estafet kepemimpinan bangsa ini.

Pendidikan karakter dapat di integrasikan dalam pembelajaran pada setiap mata pelajaran. Misalnya pembelajaran yang berkaitan dengan norma atau nilai-nilai. pada setiap mata pelajaran perlu di kembangkan, dieksplisitkan, di kaitkan dengan konteks kehidupan sehari-hari. Dengan demikin pembelajaran nilai-nilai karakter tidak hanya pada tataran kognitif, tetapi menyentuh pada internalisai, dan pengamalan nyata dalam kehidupan peserta didik sehari-hari di masyarakat.3 Pembinaan akhlaq juga dilakukan dengan menerapkan sifat - sifat yaitu Shiddiq, yang berarti jujur, Amanah, yang berarti dapat dipercaya dalam kata dan perbuatannya, Tabligh, yang berarti menyampaikan apa saja yang diterimanya dari Allah (wahyu) kepada umat manusia dan Fathanah, yang berarti berarti cerdas atau pandai.4 Merumuskan tujuan kegiatan pembinaan keagamaan sangat penting dilakukan. Tujuan tersebut harus jelas dan berorientasi pada siswa sehingga dapat merubah sikap dan tingkah laku (etika) pada diri siswa itu sendiri serta memeliki budi pekerti yang luhur dalam kehidupan sehari-hari.

Sekolah sebagai lembaga pendidikan ikut bertanggung jawab dalam mengembangkan akhlak, sekolah bukan hanya berperan sebagai transfer of knowledge tetapi bisa menjadi solusi terhadap segala problematika kehidupan remaja. Menjaga citra baik sekolah dengan mewujudkan cita-cita mulianya membentuk manusia yang bertakwa memang bukan tugas sekolah saja. Tetapi peran aktif masyarakat terutama orang tua sangat dibutuhkan. Tentu saja sekolah mengambil

\footnotetext{
${ }^{1}$ Nasin Elkabumaini dan Ramat Ruhyana, Panduan ImplementasiPendidikan Budi Pekerti, (Bandung: Yrama Widya, 2016), hlm. 4

2 Zubaedi, Desain Pendidikan Karakter Konsepsi dan Aplikasi dalam Lembaga Pendidikan, (Jakarta: Kencana, 2012), hlm. 188

${ }^{3}$ Masnur Muslich, Pendidikan Karakter Menjawab Tantangan Krisis Multidimensional,(Jakarta PT: Bumi Askara, 2011), hlm. 86

${ }^{4}$ Mochtar Buchari, Panduan Pendidikan Karakter Untuk SMP, (Kementerian Pendidikan Nasional, 2010), hlm. 45
} 
porsi peran yang lebih signifikan mengingat ia telah diamanahi oleh orang tua, masyarakat dan negara untuk mewujudkan cita-citanya. Bagaimana model usahausaha sekolah untuk membina di sekolah yang dengan itu diharapkan bisa membantu mempercepat perwujudan dari cita-cita pendidikan dalam pembinaan akhlak bagi para siswa. Di SMK Ma'arif 1 Kebumen terdapat model pembinaan akhlak terhadap siswanya diantaranya adalah model integrasi sekolah dengan pondok pesantren. Di pesantren inilah penanaman nilai nilai kebaikan tidak hanya bersifat teoritis tetapi menjadi amaliah dalam kehidupan sehari-hari. Berdasarkan latar belakang tersebut penulis tertarik untuk meneliti Model Pembinaan Akhlak Siswa di SMK Ma'arif 1 Kebumen.

\section{A. Jenis Penelitian}

\section{METODE}

Penelitian ini merupakan jenis penelitian lapangan (field research) dengan pendekatan kualitatif. Dalam penelitian ini ditunjang pula dengan library research (kepustakaan), yaitu sumber data yang berupa buku-buku atau literatur yang berkaitan dengan pembahasan.

B. Teknik Pengumpulan Data

Teknik pengumpulan data adalah cara yang ditempuh untuk mendapatkan data yang terjadi pada subjek penelitian. Teknik pengumpulan data dalam penelitian ini adalah observasi, wawancara dan dokumentasi.

C. Teknik Analisis Data

Adapun langkah-langkah dalam teknik analisis data dalam penelitian ini adalah analisis data sebelum di lapangan dan analisis data selama di lapangan.

Setelah melakukan studi pendahuluan dan menentukan fokus penelitian, selanjutnya dilakukan pengumpulan data di lapangan. Kemudian selama melakukan analisis terdapat beberapa hal yang dilakukan, antara lain reduksi data, display data, verifikasi dan simpulan

\section{A. Deskripsi Lokasi Penelitian}

\section{HASIL DAN PEMBAHASAN}

SMK Ma'arif 1 berdiri ${ }^{5}$ sejak 14 Maret 1990 merupakan salah satu Sekolah Kejuruan dibawah naungan PC.LP Ma'arif Nahdlatul Ulama. Program Keahlian yang dimiliki SMK Ma'arif 1Kebumen meliputi Kompetensi Keahlian Kendaraan Ringan (Otomotif) Kompetensi Keahlian Audio Video, Elektronika Industri, dan Multimedia. Pada tahun 2007 SMK Ma'arif 1 Kebumen telah bersertifikat menggunakan Manajemen yang diakui dan mendapatkan sertifikat ISO 9001 : 2000 dan sekarang berubah menjadi SMM ISO 9001 : 2008 dari PT TUV International. Tujuan Pendidikan Menengah Kejuruan adalah:

1. Menyiapkan peserta didik untuk memasuki lapangan kerja serta mengembangkan sikap profesional.

2. Menyiapkan peserta didik agar mampu memilih karier, mampu berkompetensi dan mampu mengembangkan diri.

3. Menyiapkan tenaga kerja tingkat menengah untuk memenuhi kebutuhan dunia usaha dan industri pada saat ini maupun akan datang.

4. Menyiapkan tamatan agar menjadi warga Negara yang taqwa, kreatif berakhlaqul karimah serta mampu berwirausaha.

Visi adalah "Mewujudkan insan didik berkriteria Tri Muttiah, yakni : Mu'min, Mutaqin, Mukhsin, Terampil dibidang Teknologi dan Informasi Global, Serta berjiwa Ahlus sunah Waljama'ah An Nahdliyah." Adapaun misinya adalah Membentuk peserta didik menjadi :

\footnotetext{
${ }^{5}$ Wawancara dengan Subkhan, Kepala Sekolah SMK Ma'arif 1 Kebumen pada tanggal 16 Juni 2019
} 
1. Bertaqwa dan berakhlaqul karimah.

2. Berkopetensi di bidang keahlian yang dipilihnya

3. Memiliki kepedulian terhadap lingkungan dan masyarakat.

B. Metode Pembinaan Akhlak di SMK Ma'arif 1 Kebumen

Banyak kegiatan yang dilakukan bertujuan untuk membentuk akhlak yang muliah. SMK Ma'arif 1 Kebumen terintegrasi dengan pondok pesantren, pendirian pondok pesantren di lingkungan sekolah juga menjadi langkah serius yang dilakukan pihak sekolah untuk membentuk akhlak yang muliah. Beberapa metode pembinaan akhlak diantaranya adalah: 6

1. Integrasi sekolah dan pondok pesantren

Mempertimbangkan posisi pesantren yang amat penting dan strategis ini maka disana dijalankan program kegiatan yang harus diikuti oleh sebagaian siswa. Program itu misalnya, pengembangan kemampuan bahasa Arab, kajian kitab kuning yang bersifat amaliah ahlu sunah waljama'ah, pembiasaan membaca Al-Qur'an, salat berjama'ah, al- barjanji, istighosah, tahlil dan kegiatan spiritual lainnya. SMK Ma'arif 1 tetap membumi dengan tetap melestarikan tradisi, menjadi wasilah bagi dunia pendidikan tradisional agar sejajar dengan pendidikan formal. Karena pesantren merupakan lembaga pendidikan Islam tradisional, sekalipun berjalan sederhana tetapi ternyata telah berhasil melahirkan para tokoh diberbagai tingkatan. Siswa adalah pilar penyanggah perjuangan generasi ke generasi dimana peran sosialnya dalam sejarah dituntut untuk bisa mencerminkan yang baik dalam sisi intelektual, spiritual dan bahkan emosionalnya.

Kesulitan yang dihadapi tatkala melengkapi sekolah dengan pesantren ternyata bukan terletak pada kesulitan mengumpulkan dana, membangun sarana fisik dan segala kelengkapannya, melainkan pada membangun kultul ma'had itu sendiri. Pesantren pada umumnya lahir dan berkembang secara evolutif. Perkembangan yang melewati waktu panjang, biasanya antara kyai dan santri saling belajar secara terus menerus untuk selalu memperbaiki dirinya. Ini adalah upaya real dalam memajukan kampus dengan penggabungan antara tradisi pesantren dan sekolah. Pesantren dikenal sebagai wahana yang berhasil melahirkan manusia-manusia yang mengedepankan dzikir, sedangkan sekolah dikenal mampu melahirkan manusia yang mempunyai nalar kritis dan selanjutnya atas dasar kedua kekuatan itu melahirkan manusia beramal sholeh.

Tidak diragukan lagi, peran pesantren sebagai benteng kokoh yang masih memegang teguh nilai-nilai luhur kemanusiaan. Nilai-nilai yang semakin lama, sedikit demi sedikit tergerus dampak era globalisasi dan modernisasi. Pesantren menjadi basis penanaman moral dan prinsip-prinsip hidup seperti kedisiplinan, keikhlasan, kesederhanaan dan kemandirian. Penanaman nilai-nilai tersebut tertanam pada tradisi dan aktifitas yang dijalankan dalam pesantren. Pesantren sesungguhnya bisa mengambil peran yang lebih besar daripada apa yang telah diperbuatnya selama ini.

2. Kegiatan pada waktu bulan ramadhan

Guna mengisi bulan Ramadhan dengan kegiatan-kegiatan yang bernuansa religius, sekolah merancang beberapa kegiatan, antara lain: buka puasa bersama, kajian kitab, kultum dan shalat taraweh. Beberapa nilai yang diharapkan dari pelaksanaan kegiatan dibulan ramadhan yaitu: Pertama, adanya penanaman nilai moral, keimanan dan ketaqwaan serta akhlakul karimah. Kedua, penerapan disiplin kebersamaan dan mengembangkan kreativitas, diarahkan pada kemandirian peserta didik. Ketiga, mengembangkan solidaritas sosial dan kesetiakawanan sosial. Selain itu, juga diupayakan adanya hubungan kekerabatan antara pembina dan siswa

\footnotetext{
${ }^{6}$ Wawancara dengan Gus Johan, Guru Pendidikan Agama Islam SMK Ma'arif 1 Kebumen pada tanggal 16 Juni 2019
} 


\section{PHBI (Peringatan Hari Besar Islam)}

Peringatan Hari Besar Islam di antaranya adalah memperingati Maulid Nabi Muhammad saw, Isra' Mi'raj, Tahun Baru Hijriyah, dan lainnya. Ada yang dilaksanakan di sekolah dengan melibatkan semua unsur sekolah. Pelaksanaan Hari Besar Islam di lingkungan sekolah bisa menjadi ajang dakwah sekolah. Sehingga para siswa akan semakin mengenal ajaran-ajaran islam dan bisa mengambil hikmah setiap peringatan hari besar Islam. Seperti peringatan Maulid Nabi Muhamad saw, kita bisa meneladani akhlak beliau dalam menyampaikan ajaran Islam dengan akhlak yang sangat baik dan menjadi suri tauladan bagi manusia alam semesta.

4. Melalui kegiatan pramuka

Melalui kegiatan pramuka pendidikan yang dilakukan di luar lingkungan sekolah dan di luar lingkungan keluarga dalam bentuk kegiatan yang menarik, menyenangkan, sehat, teratur, terarah, dan praktis yang dilakukan di alam terbuka dengan prinsip dasar dan metode kepramukaan .dengan kegiatan pramuka diharapkan dapat:

a. Membentuk karakter/ kepribadian dan akhlak yang mulia para generasi muda.

b. Menanamkan rasa cinta tanah air dan bangsa di dalam diri generasi muda.

c. Menggali potensi diri dan meningkatkan keterampilan para generasi muda sehingga menjadi individu yang bermanfaat bagi masyarakta dan negara.

5. Pembinaan oleh Kodim 0709 Kebumen

Tujuan dari pembinaan dilakukan oleh TNI adalah menanamkan jiwa nasionalisme, patriotisme, kedisiplinan, menjauhi narkoba, minuman keras. Terus yang penting lagi adalah jangan sampai para siswa terjangkit penyakit radikalimse, yang saat ini sudah mulai disebarkan mulai usia belia.

\section{SIMPULAN}

Berdasarkan uraian pembahasan hasil penelitian pada bab sebelumnya, maka penulis dapat menarik kesimpulan penelitian ini sebagai berikut:

Model pembinaan akhlak di SMK Ma'arif 1 Kebumen, dapat berjalan dengan baik karena adanya kerjasama antara sekolah, orang tua dan masyarakat. Kegiatan tersebut dapat memberikan sumbangsih pada pembinaan akhlak. Pembinaan pembinaan akhlak di SMK Ma'arif 1 Kebumenntegrasi sekolah dan pondok pesantren, kegiatan pada Waktu Bulan Ramadhan, HBI (Peringatan Hari Besar Islam), pramuka, pembinaan dari kodim 0709 Kebumen.

Hendaknya diusaha dari pihak sekolah untuk memberikan waktu yang optimal terhadap kegiatan keagamaan ini, dikarenakan kegiatan ini merupakan media untuk mendukung pelajaran agama yang dilaksanakan di dalam kelas. Dan diprogramkan secara menarik dan bervariasi, sehingga dapat memotivasi siswa dan tidak merasa jenuh untuk mengikuti kegiatan yang diselenggarakan dalam rangka pembinaan akhlak bagi siswa di SMK Ma'arif 1 Kebumen.

\section{DAFTAR PUSTAKA}

Buchari, Mochtar. (2010). Panduan Pendidikan Karakter Untuk SMP. Kementerian Pendidikan Nasional

Elkabumaini, Nasin \& Ramat Ruhyana. (2016). Panduan ImplementasiPendidikan Budi Pekerti. Bandung: Yrama Widya

Muslich, Mansur. (2011). Pendidikan Karakter Menjawab Tantangan Krisis Multidimensional. Jakarta PT: Bumi Askara

Wawancara dengan Gus Johan, Guru Pendidikan Agama Islam SMK Ma'arif 1 Kebumen pada tanggal 16 Juni 2019

Wawancara dengan Subkhan, Kepala Sekolah SMK Ma'arif 1 Kebumen pada tanggal 16 Juni 2019

Zubaedi. ( 2012). Desain Pendidikan Karakter Konsepsi dan Aplikasi dalam Lembaga Pendidikan. Jakarta: Kencana 